International Journal of Current Advanced Research

ISSN: O: 2319-6475, ISSN: P: 2319 - 6505, Impact Factor: SJIF: 5.995

Available Online at www.journalijcar.org

Volume 6; Issue 3; March 2017; Page No. 2631-2633

DOI: http://dx.doi.org/10.24327/ijcar.2017.2633.0061

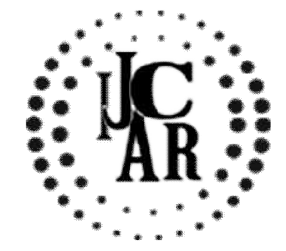

Research Article

\title{
SOURCES OF KNOWLEDGE, AND AWARENESS REGARDING HYPERTENSION AMONG MEDICAL STUDENTS- THE INFLUENCE OF GENDER
}

\author{
Ramaprabha $\mathbf{P}^{1}{ }^{*}$, Dhandapany Senthil Pragash ${ }^{2}$ and Aravindkumar $\mathbf{R}^{3}$ \\ ${ }^{1}$ Department of Physiology, DM WIMS Medical College, Wayanad, Kerala. 673577 \\ ${ }^{2}$ Department of Microbiology, Melmaruvathur Adhiparasakthi Institute of Medical \\ Sciences and Research, Melmaruvathur, Tamilnadu - 603319.
}

${ }^{3}$ Department of Physiology, Rajah Muthiah Medical College, Annamalai University, Annamalai Nagar, Tamil Nadu 608002

\section{A R T I C L E I N F O}

\section{Article History:}

Received $8^{\text {th }}$ December, 2016

Received in revised form $26^{\text {th }}$ January, 2017

Accepted $6^{\text {th }}$ February, 2017

Published online $28^{\text {th }}$ March, 2017

\section{Key words:}

Hypertension, First-year MBBS, Gender, Knowledge

\begin{abstract}
A B S T R A C T
Background: Hypertension is one of the major risk factors for development of cardiovascular diseases and Non-Communicable Diseases (NCDs). This study was conducted to ascertain if there is a difference in knowledge regarding diagnosis, risk factors and complications of hypertension between male and female first year MBBS students. Methods: This cross-sectional study was conducted in a private medical college in Tamil Nadu. After obtaining Institutional Ethical Committee approval and written informed consent from students, 150 first year medical students were recruited for the study. A structured, pre-tested questionnaire was administered to study subjects. Chi-square test was performed to determine statistical significance. Results: 149 respondents were included in the analyses. There were $75(50.3 \%)$ male and 74(49.6\%) female respondents. While $55(73.3 \%)$ of male respondents, and $65(87.8 \%)$ of female respondents identified high salt diet as a risk factor, $20(26.7 \%)$ male and $9(12.2 \%)$ female respondents did not. This difference was statistically significant, with a $\mathrm{p}$ value of 0.03 . The top three sources of information regarding hypertension were friends, school and doctors, respectively. Conclusions: Significantly more male students were unaware of high salt diet as a risk factor for hypertension compared to female students. Most students obtained information about hypertension from their friends.
\end{abstract}

Copyright $₫ 2017$ Ramaprabha P et al. This is an open access article distributed under the Creative Commons Attribution License, which permits unrestricted use, distribution, and reproduction in any medium, provided the original work is properly cited.

\section{INTRODUCTION}

Hypertension is one of the major risk factors for the development of Non-Communicable Diseases (NCDs) in general and cardiovascular disease in particular (WHO SouthEast Asia Region Office, 2013; World Health Organization, 2016a). It is a major public health problem, and was the World Health Day theme in 2013 (WHO South-East Asia Region Office, 2013b).

Contrary to popular perception, hypertension affects more people in low and middle-income countries than high-income countries(WHO South-East Asia Region Office, 2013; World Health Organization, 2016b). Although several investigators have examined the prevalence of hypertension and risk of developing NCDs among medical students, there is a paucity of literature regarding medical students' knowledge about hypertension (Chattopadhyay et al., 2014; Paul, Nayaki, Sen, \& Isaac, 2015; Shaikh et al., 2011).

\section{*Corresponding author: Ramaprabha $\mathbf{P}$}

Department of Physiology, DM WIMS Medical College, Wayanad, Kerala. 673577
This study was conducted in a private medical college in south India to identify the sources of knowledge regarding hypertension among first year MBBS students; and determine if gender influences awareness of hypertension.

\section{MATERIALS AND METHODS}

This cross-sectional study was conducted in Melmaruvathur Adhiparasakthi Institute of Medical Sciences and Research,a private medical college in Tamil Nadu, India. The annual intake of students for the MBBS course is 150, and we decided to include all 150 students in the study.

The study was restricted to first year MBBS students of the 2013 admission batch, who had completed six months' study, and had not been formally taught about hypertension.

After obtaining permission to conduct the study from the Institutional Ethics Committee (approval number 68(1-A) 2013), students were invited to participate in the study.Written informed consent was obtained from all students. No student refused to participate in the study. However, one student submitted an incomplete study tool, hence was excluded from analyses. 
A pre-tested, structured questionnaire was administered to the students. It included questions regarding diagnosis, risk factors, and complications of hypertension.

Data entry and transformation were performed using Microsoft Office Excel 2010. Data analyses were performed using EZR (version 1.34 ( $\mathrm{R}$ Commander version 2.30))(Kanda, 2013). Descriptive statistics, and chi-square test were performed. Statistical significance was set at the $5 \%$ level.

\section{RESULTS}

There were almost equal number of male $(75[50.3 \%])$ and female $(74[49.6 \%])$ students.

$66(44.3 \%)$ of respondents reported that their mother had completed graduation or post-graduation, while $22(14.7 \%)$ and $21(14.1 \%)$ reported maternal education as PUC/Higher Secondary and Professional/Honours respectively.

$59(39.6 \%)$ of respondents reported their father's educational qualification as graduate/ post-graduate, while 35 (23.5\%) and $24(16.1 \%)$ reported paternal education as PUC/Higher Secondary and Professional/Honours respectively.

There was no statistically significant difference in educational qualifications of parents between male and female respondents.

Table 1 Gender-wise responses to questions

\begin{tabular}{|c|c|c|c|c|}
\hline Item & Response & Male n(\%) & Female n(\%) & p value \\
\hline What is & Increase in BP & $75(100)$ & $72(97.3)$ & \\
\hline hypertension? & Others & $0(0)$ & $2(2.7)$ & 0.24 \\
\hline & $120 / 80 \mathrm{~mm} \mathrm{Hg}$ & $61(81.3)$ & $61(82.4)$ & \\
\hline Normal BP is & Others & $14(18.7)$ & $13(17.6)$ & 1 \\
\hline \multicolumn{5}{|c|}{ Risk Factors for developing hypertension include: } \\
\hline \multirow{2}{*}{ Stress } & Yes & $73(97.3)$ & $73(98.6)$ & \multirow{2}{*}{1} \\
\hline & No/ Don't know & $2(2.7)$ & $1(1.4)$ & \\
\hline \multirow{2}{*}{ Alcohol } & Yes & $43(57.3)$ & $47(63.5)$ & \multirow{2}{*}{0.50} \\
\hline & No/ Don't know & $32(42.7)$ & $27(36.5)$ & \\
\hline \multirow{2}{*}{ Diabetes Mellitus } & Yes & $49(65.3)$ & $51(68.9)$ & \multirow{2}{*}{0.72} \\
\hline & No/ Don't know & $26(34.7)$ & $23(31.1)$ & \\
\hline \multirow{2}{*}{ Adrenal Disease } & Yes & $37(49.3)$ & $38(51.4)$ & \multirow{2}{*}{0.87} \\
\hline & No/ Don't know & $38(50.7)$ & $36(48.6)$ & \\
\hline \multirow{2}{*}{ Family history } & Yes & $27(36)$ & $29(39.2)$ & \multirow{2}{*}{0.73} \\
\hline & No/ Don't know & $48(64)$ & $45(60.8)$ & \\
\hline \multirow{2}{*}{ High fat diet } & Yes & $59(78.7)$ & $58(78.4)$ & \multirow{2}{*}{1} \\
\hline & No/ Don't know & $16(21.3)$ & $16(21.6)$ & \\
\hline \multirow{2}{*}{ High salt diet } & Yes & $55(73.3)$ & $65(87.8)$ & \multirow{2}{*}{0.03} \\
\hline & No/ Don't know & $20(26.7)$ & $9(12.2)$ & \\
\hline \multirow{2}{*}{ Malnutrition } & Yes & $7(9.3)$ & $8(10.8)$ & \multirow{2}{*}{0.79} \\
\hline & No/ Don't know & $68(90.7)$ & $66(89.2)$ & \\
\hline \multirow{2}{*}{ Obesity } & Yes & $68(90.7)$ & $66(89.2)$ & \multirow{2}{*}{0.79} \\
\hline & No/ Don't know & $7(9.3)$ & $8(10.8)$ & \\
\hline \multirow{2}{*}{ Old age } & Yes & $63(84)$ & $55(74.3)$ & \multirow{2}{*}{0.12} \\
\hline & No/ Don't know & $12(16)$ & $19(25.7)$ & \\
\hline \multirow{2}{*}{ Sedentary lifestyle } & Yes & $32(42.7)$ & 31 (41.9) & \multirow{2}{*}{1} \\
\hline & 'No/Don't know & $43(57.3)$ & $43(58.1)$ & \\
\hline \multirow{3}{*}{$\begin{array}{c}\text { Hypertension is } \\
\text { detected }\end{array}$} & \multicolumn{3}{|c|}{ Diagnosis } & \multirow{3}{*}{0.36} \\
\hline & $\begin{array}{l}\text { By regular BP } \\
\text { monitoring }\end{array}$ & $71(94.7)$ & $73(98.6)$ & \\
\hline & Others & $4(5.3)$ & $1(1.4)$ & \\
\hline \multirow{3}{*}{$\begin{array}{l}\text { Complications of } \\
\text { hypertension are }\end{array}$} & Com & plications & & \multirow{3}{*}{0.44} \\
\hline & $\begin{array}{l}\text { Heart failure, } \\
\text { stroke, renal } \\
\text { disease }\end{array}$ & $70(93.3)$ & $72(97.3)$ & \\
\hline & Others & $5(6.7)$ & $2(2.7)$ & \\
\hline
\end{tabular}

As can be seen from the table above, almost all students correctly described hypertension as an increase in blood pressure; and just over $80 \%$ correctly identified the normal Blood Pressure (BP) values.
Obesity, old age and a high fat diet were identified as risk factors by approximately $90 \%, 80 \%$, and $78 \%$ of respondents, respectively. However, only around $42 \%$ of respondents considered sedentary lifestyle as a risk factor for hypertension. While 55(73.3\%) of male respondents, and $65(87.8 \%)$ of female respondents identified high salt diet as a risk factor, $20(26.7 \%)$ male and $9(12.2 \%)$ female respondents did not. This difference was statistically significant, with a $p$ value of 0.03 .

Although around $65 \%$ of students identified diabetes mellitus as a risk factor, $60 \%$ of female students and $65 \%$ male students did not identify family history as a risk factor for developing hypertension.

Similarly, almost all students identified stress as a risk factor for development of hypertension. However, around $40 \%$ of students did not consider alcohol consumption as a risk factor for hypertension. The proportion of respondents who did not consider adrenal disease as a risk factor for developing hypertension was about $50 \%$.

Except for five respondents, all others correctly mentioned how hypertension is diagnosed.

Similarly, around $95 \%$ of respondents correctly identified the complications of hypertension.

Details regarding the source of information are provided in table 2 .

Table 2 Sources of information regarding hypertension by gender

\begin{tabular}{ccccc}
\hline Item & Response & Male n(\%) & Female n(\%) & p value \\
\hline \multirow{2}{*}{ Friends } & Yes & $66(88)$ & $67(90.5)$ & \multirow{2}{*}{0.79} \\
& No & $9(12)$ & $7(9.5)$ & \\
School & Yes & $60(80)$ & $62(83.8)$ & 0.67 \\
& No & $15(20)$ & $12(16.2)$ & \\
Doctors & Yes & $57(76)$ & $61(82.4)$ & 0.42 \\
& No & $18(24)$ & $13(17.6)$ & \\
Television & Yes & $42(56)$ & $48(64.9)$ & 0.31 \\
& No & $33(44)$ & $26(35.1)$ & \\
Internet & Yes & $41(54.7)$ & $38(51.4)$ & 0.74 \\
& No & $34(45.3)$ & $36(48.6)$ & \\
Health workers & Yes & $24(32)$ & $26(35.1)$ & 0.73 \\
& No & $51(68)$ & $48(64.9)$ & \\
News & Yes & $23(30.7)$ & $17(23)$ & 0.35 \\
& No & $52(69.3)$ & $57(77)$ & \\
Others & Yes & $13(17.3)$ & $6(8.1)$ & 0.13 \\
Radio & No & $62(82.7)$ & $68(91.9)$ & \multirow{2}{*}{1} \\
& Yes & $8(10.7)$ & $8(10.8)$ & 1 \\
& No & $67(89.3)$ & $66(89.2)$ & \\
\hline
\end{tabular}

As depicted in table 2, the top three sources of information regarding hypertension were friends $(\sim 90 \%)$; school $(\sim 81 \%)$; and doctors $(\sim 78 \%)$.

$13(17.3 \%)$ male respondents reported obtaining information from other sources. This was over twice the number of female respondents reporting the same, but did not reach statistical significance.

\section{DISCUSSION}

From the results, it is clear that even before they are formally taught about hypertension, most medical students know the basics of the condition- what it is, and what normal blood pressure values are.

However, there are significant gaps in their knowledge, as they fail to recognize several risk factors as important in disease causation. 
Although obesity and high fat diet were identified as risk factors for hypertension, less than $50 \%$ respondents associated sedentary lifestyle with it. This is ironic, considering the relationship between sedentary lifestyle, high fat high sugar diet, and development of obesity. However, this is consistent with the findings of Shaikh et al, who reported that only $47 \%$ students mentioned physical inactivity as a risk factor for hypertension (Shaikh et al., 2011)

A significantly higher proportion of male respondents failed to identify high salt diet as a risk factor for the development of hypertension. Perhaps this reflects greater awareness regarding the role of dietary factors, especially sodium(Adrogue \& Madias, 2014) among female students. Shaikh et al reported that $69.1 \%$ of students in their study identified high salt intake as a risk factor for hypertension (Shaikh et al., 2011). The awareness of students in this study regarding high salt is considerably higher, with over $73 \%$ male and $87 \%$ female students indicating it as a risk factor.

Contrary to expectations, most (60-65\%) students failed to mention family history as a risk factor for hypertension. This was surprising as popular perceptions about hypertension include familial tendency. However, the result is similar to that reported by Shaikh et al, who found that $50 \%$ of respondents in their study did not identify family history of cardiovascular disease as a risk factor for hypertension (Shaikh et al., 2011)

Less than $10 \%$ of respondents identified malnutrition as a risk factor for hypertension. This could be on account of the assumption that malnutrition (protein energy malnutrition) is on the opposite end of the spectrum from obesity, hence must not be associated with hypertension. Moreover, the mechanisms by which malnutrition result in hypertension have been described only recently (Tennant et al., 2014).

Perhaps due to depictions in mass media, almost all students identified stress and advancing age as risk factors for hypertension. Shaikh and colleagues reported similar findings from their study, with $75.5 \%$ respondents mentioning it as a risk factor for hypertension (Shaikh et al., 2011).

However, adrenal disease was considered a factor by only $50 \%$ of respondents. This is interesting on account of the relationship between the adrenal hormones and stress.

Most students reported that the source of their knowledge regarding hypertension were friends, followed by school and doctors. This highlights the importance of peer groups- if the peers have correct knowledge about the condition, it may benefit all within the peer group. However, the reverse could also be true.

It was interesting to note that more students gained information about hypertension from school than doctors, underscoring the importance of schools in health education and awareness creation.

Although we did not find a statistically significant difference between the sexes in terms of source of information, many more (over twice as many female students) male respondents reported obtaining information from other sources.

Other sources that were expected to rank higher in the list included internet and radio. However, these were not as popular as the top three sources mentioned above.

\section{CONCLUSIONS}

From this study we found that there was a statistically significant difference in knowledge regarding high salt diet as a risk factor for hypertension between male and female first year medical students. The commonest sources of information regarding hypertension were friends, followed by school.

\section{Ackowledgements}

We would like to thank the students who participated in the study, and Dr.Liaquat Roopesh Johnson, who provided technical assistance in preparation of this article.

\section{References}

Adrogue, H. J., \& Madias, N. E. (2014). Sodium surfeit and potassium deficit: Keys to the pathogenesis of hypertension. Journal of the American Society of Hypertension, 8(3), 203213. https://doi.org/10.1016/ j.jash.2013.09.003

Chattopadhyay, A., Taraphdar, P., Kumarsahu, B., Maulik, S., Ghosh, R., Sinha, A., \& Biswas, M. (2014). A study on prevalence of Hypertension and its related risk factors among undergraduate medical students in Kolkata. IOSR Journal of Dental and Medical Sciences, 13(11), 2279-861. Retrieved from www.iosrjournals.org

Kanda, Y. (2013). Investigation of the freely available easy-touse software "EZR" for medical statistics. Bone Marrow Transplantation, 48(October 2012), 452-458. https://doi.org/10.1038/bmt.2012.244

Paul, B., Nayaki, V., Sen, M., \& Isaac, R. (2015). Prevalence of Cardiovascular Disease risk Among Medical Students in South India. Indian Journal of Community Health Indian J Comm Health, 27(2), 211-215.

Shaikh, R. B., Mathew, E., Sreedharan, J., Muttappallymyalil, J., Sharbatti, S. Al, \& Basha, S. a. (2011). Knowledge regarding risk factors of hypertension among entry year students of a medical university. Journal of Family and Community Medicine, 18(3), 124-9. https://doi.org/ 10.4103/2230-8229.90011

Tennant, I. A., Barnett, A. T., Thompson, D. S., Kips, J., Boyne, M. S., Chung, E. E., ... Forrester, T. E. (2014). Impaired cardiovascular structure and function in adult survivors of severe acute malnutrition. Hypertension, 64(3), 664-671. https://doi.org/10.1161/ Hypertensionaha. 114.03230

WHO South-East Asia Region Office. (2013). HIGH Blood Pressure A Public Health Priority. New Delhi. Retrieved from http:/www.searo.who.int/entity/world_ health_day/ leaflet_public_health_priority_hbp_ncd_whd_2013_factbuff et.pdf?ua $=1$

WHO South-East Asia Region Office. (2013). High Blood Pressure Global and Regional Overview. New Delhi. Retrieved from http://www.searo.who.int/entity/ world health_day/leaflet_burden_hbp_whd_2013.pdf?ua=1

WHO South-East Asia Region Office. (2013). World Health Organization, World Health Day - 7 April 2013. Retrieved April 2, 2017, from http://www.searo.who.int/ entity/world_health_day/en/

World Health Organization. (2016a). Fact sheet: Cardiovascular diseases (CVDs). WHO. World Health Organization. Retrieved from http://who.int/mediacentre/ factsheets/fs317/en/

World Health Organization. (2016b). WHO | World Health Organization. Retrieved April 2, 2017, from http://gamapserver.who.int/gho/interactive_charts/ncd/risk_f actors/blood_pressure_prevalence/atlas.html 